
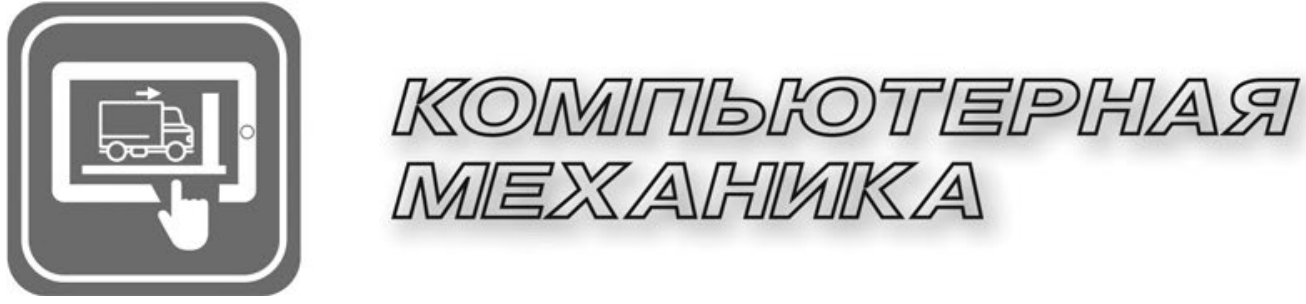

УДК 004.94:62-599

А.О. ШИМАНОВСКИЙ, д-р техн. наук, проф.

заведующий кафедрой «Техническая физика и теоретическая механика» ${ }^{1}$

E-mail: tm.belsut@gmail.com

М.Г. КУЗНЕЦОВА, канд. техн. наук, доц.

доцент кафедры «Техническая физика и теоретическая механика»'

E-mail: marina-kuzn@mail.ru

\title{
О.В. ДЕМЬЯНЧУК
}

студентка факультета «Управление процессами перевозок»'

E-mail: olga.demyanchuk.98@mail.ru

${ }^{1}$ Белорусский государственный университет транспорта, г. Гомель, Республика Беларусь

Поступила в редакиию 05.10.2021.

\section{КОМПЬЮТЕРНОЕ МОДЕЛИРОВАНИЕ ДИНАМИКИ ВЗАИМОДЕЙСТВИЯ КОЛЕСНЫХ ПАР ВАГОНОВ С ТОРМОЗНЫМИ БАШМАКАМИ}

\begin{abstract}
Рассматривается проблема удержания вагонов от скатывания на станционных железнодорожных путях с допустимым уклоном 0-2,5 \%о. Приведены результаты компьютерного моделирования динамического взаимодействия колес с установленными на рельсах тормозными баммаками в прочессе остановки вагона грузового поезда с применением стандартных тормозных башмаков в инженерном программном комплексе MSC.ADAMS. При этом учитывались различные свойства поверхности рельса, моделирующие благоприятные и неблагоприятные для торможения условия контакта между колесом, тормозным башмаком и рельсом, обусловленные как погодными условиями, так и особенностями расположения и эксплуатации станиионных путей. Исследовано взаимодействие колес вагона с максимальной нагрузкой на ось и станционных тормозных башмаков, установленных на рельсах, при различных начальных скоростях движения транспортного средства, а также при нахождении его в покое на путях с допустимым уклоном при условиях обеспечения минимального трения между колесом и рельсом, а также рельсом и башмаком, что соответствует нахождению состава на замасленных рельсах. Показано, что при превышающей $0,5 \mathrm{~m} / \mathrm{c}$ скорости наезда на расположенный на замасленных рельсах тормозной башмак не всегда возможно обеспечить удержание железнодорожного состава. При других условиях наезда колеса на тормозной башмак также возможно возникновение проблем с удержанием состава на рельсах, обусловленных такими случайными факторами, как боковая ветровая нагрузка, обледенение рельсов, изношенность и деформация поверхности колеса и тормозного башмака, уменьшающими динамический коэффициент трения между контактирующими поверхностями.
\end{abstract}

Ключевые слова: тормозной башмак, компьютерное моделирование, колесная пара, MSC.ADAMS

DOI: https://doi.org/10.46864/1995-0470-2021-4-57-48-55

Большинство станций на железных дорогах колеи 1520 мм построены до 1991 года. Допустимый уклон станционных путей в то время со- ставлял 2,5 \%о, на станциях, построенных позднее, - 1,5\% [1]. Однако даже при таких уклонах существует проблема удержания вагонов от ска- 
тывания, которая наиболее существенно проявляется при таких неблагоприятных условиях, как дождь, снег и обледенение рельсов. В настоящее время основным средством, обеспечивающим неподвижность вагонов при размещении их без локомотива на станционных путях отечественных и зарубежных железных дорог, являются тормозные башмаки $[2,3]$. Опыт эксплуатации показывает, что расчет потребного количества тормозных башмаков в соответствии с существующими нормативными документами не всегда дает удовлетворительные результаты. Актуальность проблемы подтверждается разработкой новых конструкций тормозных башмаков [4-6], однако их эффективность не доказана.

Авторами работы [7] рассмотрены недостатки применения тормозных башмаков на станциях китайских железных дорог, связанные с осуществлением их укладки и контроля нахождения вручную. Предложена система предотвращения ухода вагонов, основанная на интеллектуальных тормозных башмаках, оснащенных датчиками и системой мониторинга и управления, которая может отслеживать состояние тормозных башмаков в реальном времени. Аналогичные функции выполняет устройство, разработанное латвийскими специалистами $[8,9]$.

В статье [10] на основании анализа результатов проведенной серии испытаний по закреплению железнодорожного подвижного состава тормозными башмаками установлена необходимость пересмотра существующих норм определения по- требного их количества. В связи с этим имеется необходимость более подробного рассмотрения процессов, сопровождающих взаимодействие колесных пар с тормозными башмаками при остановке и удержании вагонов на перегоне.

Различными авторами на основе компьютерного моделирования ранее выполнялись исследования эффективности вагонных тормозных колодок при различных условиях эксплуатации $[11,12]$, а также расчеты напряженно-деформированного состояния элементов тормозных систем [13-16]. Однако компьютерное моделирование динамического взаимодействия колес с установленными на рельсах тормозными башмаками не выполнялось.

Цель представленной работы заключается в анализе эффективности тормозных башмаков при наезде на них вагона с учетом возможных различий в свойствах контакта соприкасающихся поверхностей, которые имитируют реальные эксплуатационные условия.

В программном комплексе MSC.ADAMS выполнено моделирование остановки вагона с применением тормозных башмаков. Модель представляет собой колесную пару с максимальной нагрузкой на ось, равной 25 т. Рельсы располагались горизонтально, с уклоном 1,5 \%о (1:667) и 2,5\% $\%$ (1:400). Остановка этой колесной пары производилась одним (как это происходит на практике) и двумя тормозными башмаками (рисунок 1). Максимальная начальная скорость движения колесной пары составляла 1 м/с. Также
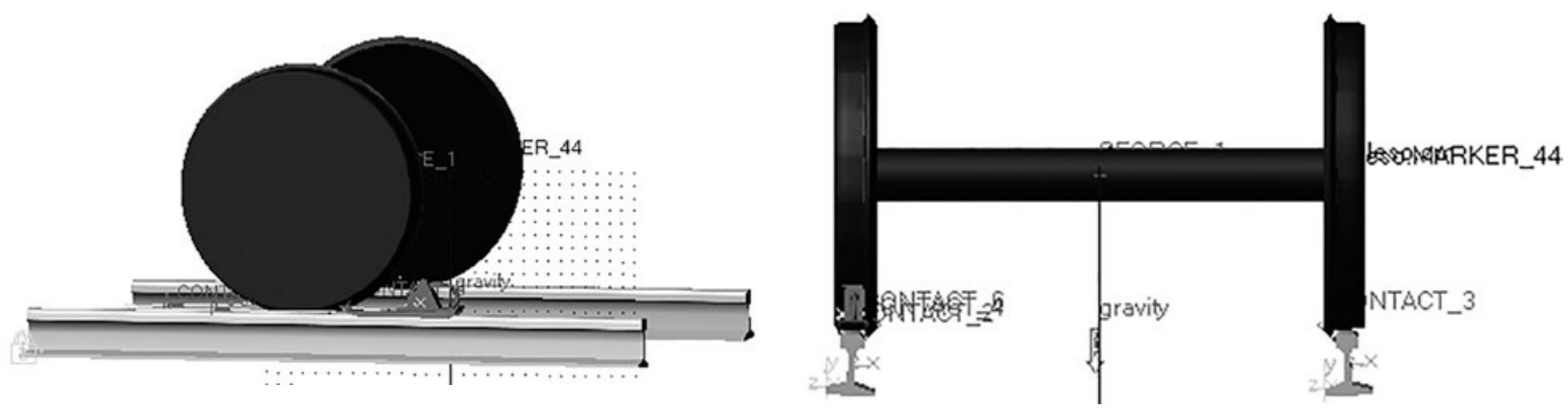

$a$
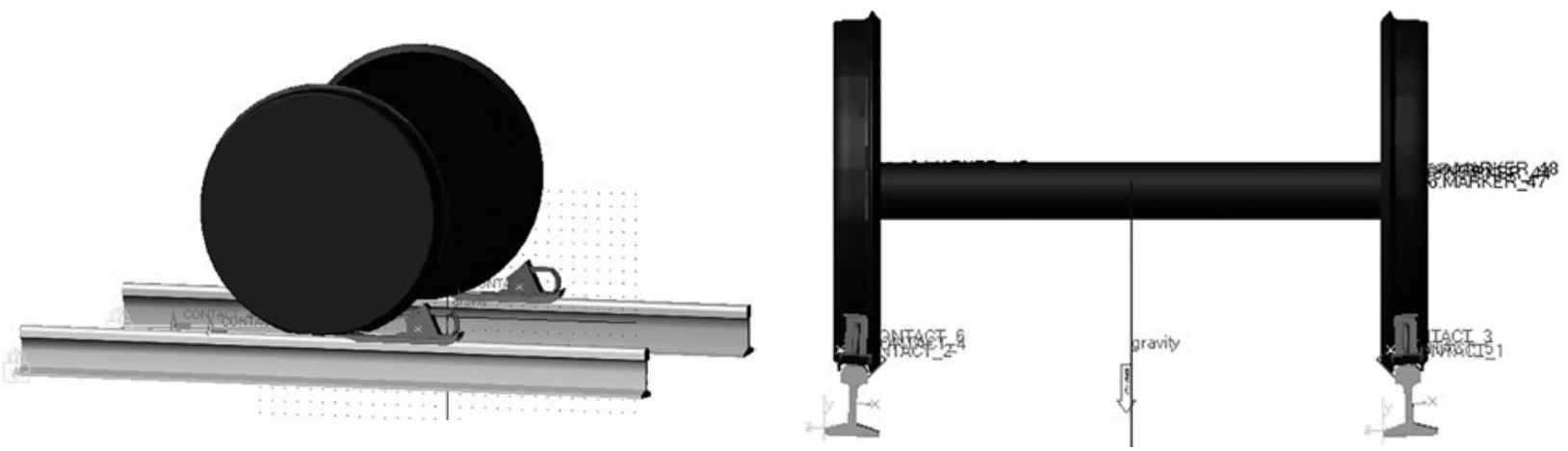

b

Рисунок 1 - Модель колесной пары, движущейся по рельсам с установленным одним (a) и двумя (b) тормозными башмаками Figure 1 - Model of a wheelset moving on rails with one $(a)$ and two $(b)$ brake shoes installed 
проводились расчеты для покоящегося вагона, т. е. при отсутствии начальной скорости движения. При этом учитывались различные свойства поверхности рельса путем изменения параметров контактного взаимодействия между колесом и рельсом. Все тела представляли собой твердые сплошные однородные объекты.

Выполнены расчеты для колесной пары при неблагоприятных условиях: поверхность рельса замасленная; коэффициент трения скольжения минимален и составляет 0,16 ; уклон станционных путей — 2,5 \%; начальная скорость движения 0,5 м/с. Результаты расчета (рисунок 2) показали, что применение одного башмака не позволяет остановить вагон, он продолжает движение вместе с тормозящим его устройством. Скорость перемещения при этом снижается, но происходит это достаточно медленно.

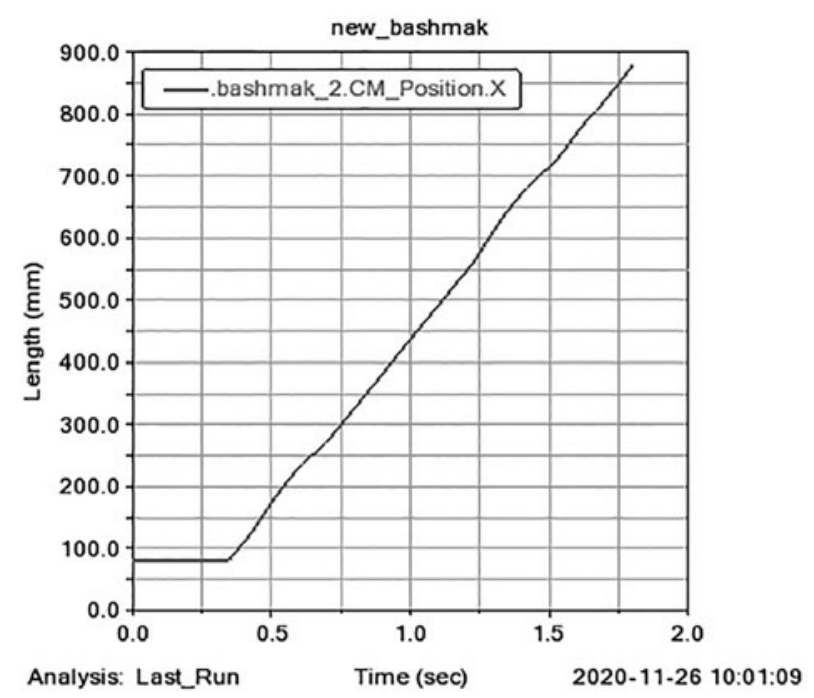

$a$

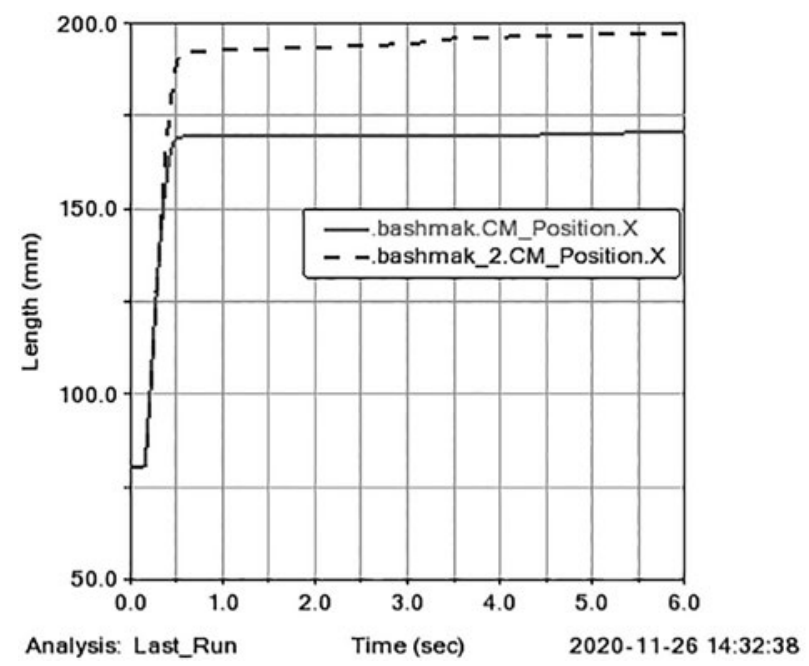

b

Рисунок 2 - Результаты расчета смещения башмаков при установке одного (a) и двух (b) единиц на рельсы при самых неблагоприятных условиях движения вагона Figure 2 - Results of calculating the displacement of shoes when installing one $(a)$ and two $(b)$ units on the rails under the most unfavorable conditions of car movement

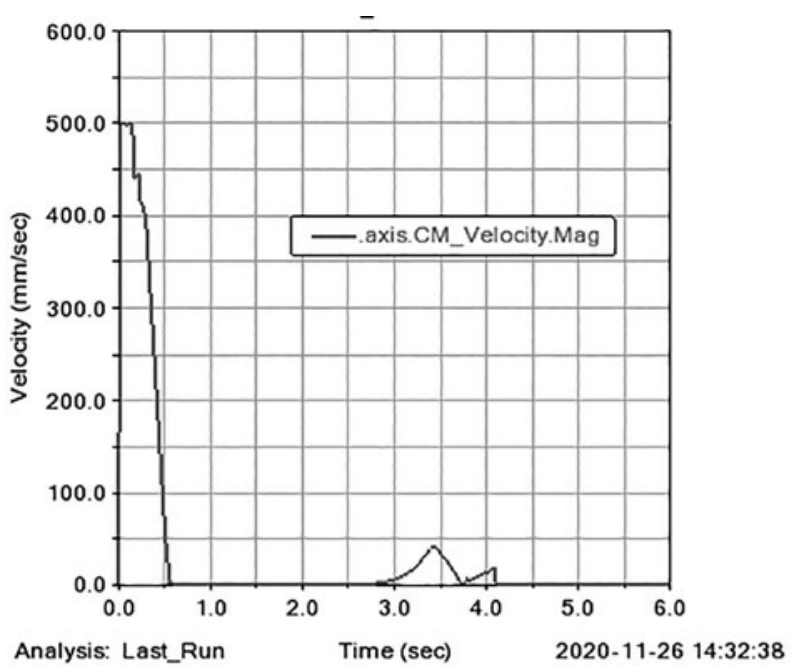

Рисунок 3 - Результаты расчета скорости оси колеса при установке двух башмаков на рельсы при неблагоприятных условиях

Figure 3 - Results of calculating the speed of the wheel axle when installing two shoes on rails under unfavorable conditions

При использовании тормозных башмаков с двух сторон они смещаются при соударении с колесами на расстояние около 100 мм, после чего колеса остаются практически в покое (рисунок 3 ). При увеличении начальной скорости движения до 1 м/с максимальное смещение башмаков составляет 450 мм (рисунок 4).

При тех же условиях, но при сухой поверхности рельса (коэффициент трения скольжения составляет 0,4) получены результаты, показанные на рисунке 5. Максимальное смещение башмаков при установке на каждом рельсе составило около 80 мм, при этом башмак с правой стороны по ходу движения вагона слетел с рельса (см. рисунок 5 b). Из рисунка 6 можно увидеть, что при соприкосновении обода колеса с накладкой башмака происходит

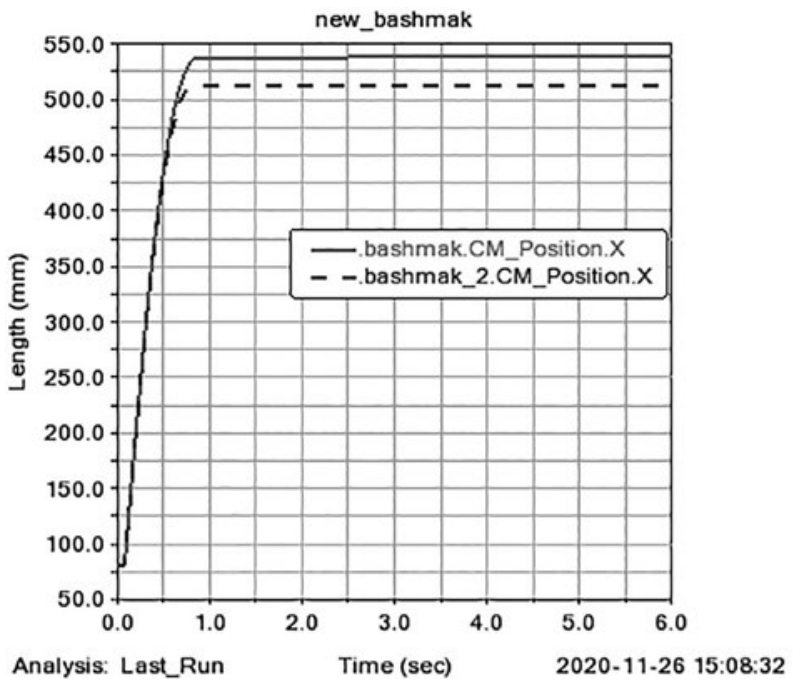

Рисунок 4 - Результаты расчета смещения тормозных башмаков при установке при неблагоприятных условиях и движении со скоростью $1 \mathrm{~m} / \mathrm{c}$

Figure 4-Results of calculating the displacement of brake shoes when installed under unfavorable conditions and moving at a speed of $1 \mathrm{~m} / \mathrm{s}$ 


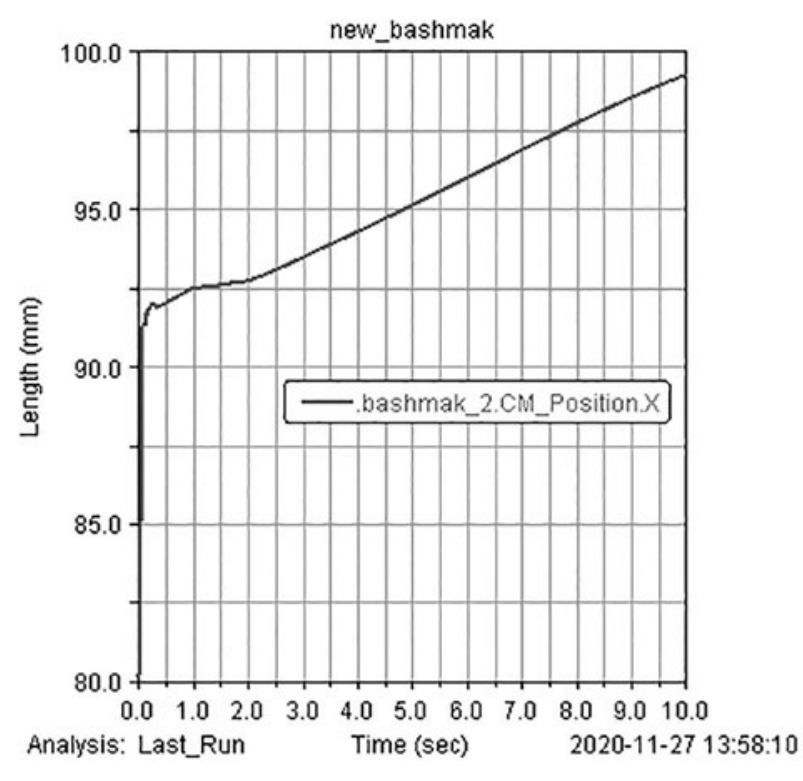

$a$

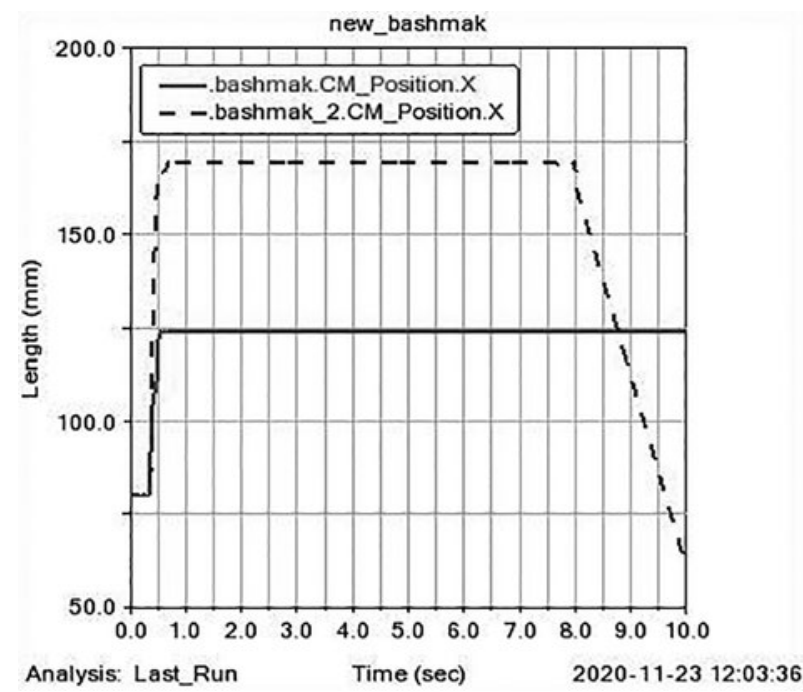

b

Рисунок 5 - Результаты расчета смещения правого по ходу движения башмака (a) и двух башмаков (b) при наезде на них колесной пары со скоростью 0,5 м/с

Figure 5 - Results of calculating the displacement

of the right shoe $(a)$ in the course of movement and two shoes $(b)$

when a wheelset hits them at a speed of $0.5 \mathrm{~m} / \mathrm{s}$

резкий откат назад, а затем колесо практически стоит на месте (смещение составляет до 6 мм).

Выполнены расчеты для колесной пары при следующих условиях: поверхность рельса замасленная; коэффициент трения скольжения минимален и составляет 0,16 ; уклон станционных путей $0 \%$; начальная скорость движения - 0,5 м/с. Один тормозной башмак не справляется с задачей и опрокидывается менее чем через 1 с после наезда колеса на него (рисунки 7, 8).

Даже при движении по горизонтальным рельсам один башмак не способен оказать удерживающее воздействие, если один из рельсов скользкий, a второй сухой. Тормозной башмак смещается и слетает с рельса (рисунок 9). Колесная пара при этом останавливается, но при учете силы,

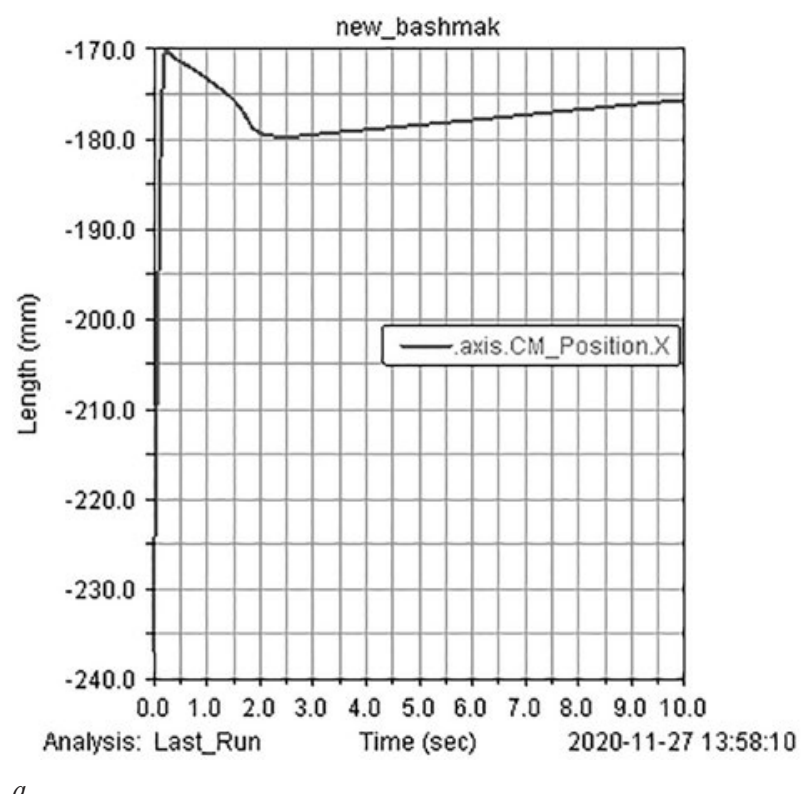

$a$

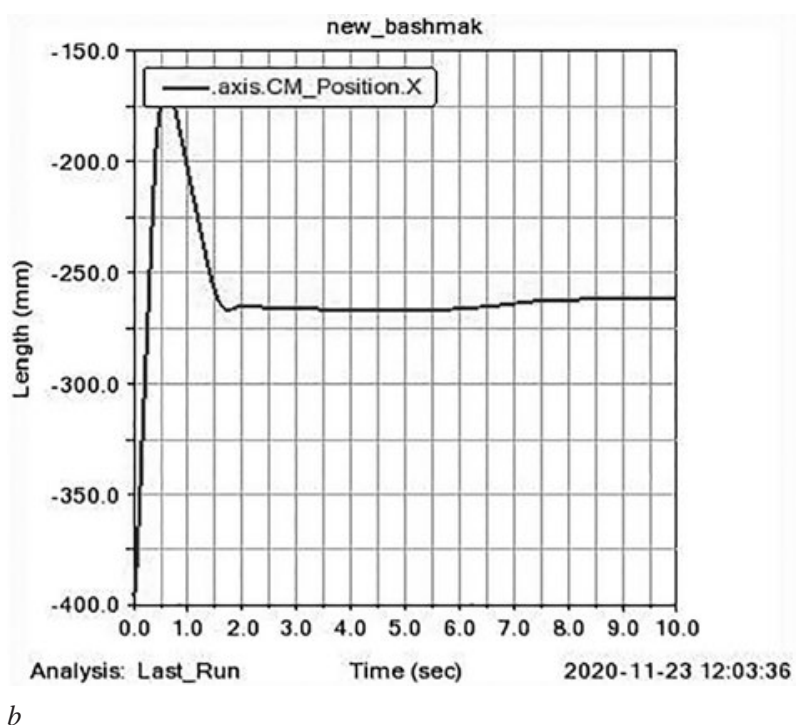

Рисунок 6 - Результаты расчета перемещения оси колеса при установке одного $(a)$ и двух $(b)$ башмаков на рельсы Figure 6 - Results of calculating the movement of the wheel axle when installing one $(a)$ and two (b) shoes on rails

обусловленной инерцией закрепляемого состава, в реальных условиях движение колес может продолжиться.

Также были рассмотрены случаи удержания покоящегося вагона на станционном пути, имеющем уклон 1,5 и 2,5%, одним башмаком при условиях обеспечения минимального трения между колесом и рельсом, а также рельсом и башмаком (скользкий рельс, коэффициент трения скольжения принят равным 0,16).

При уклоне 2,5 \%о при наезде на башмак колесо испытывает колебания в плоскости, поперечной направлению движения колесной пары (рисунки 10, 11).

При наезде на тормозной башмак колесо сначала откатывается назад, а затем возвращается и совершает колебания с амплитудой, меньшей 0,1 мм (рисунок 12). 


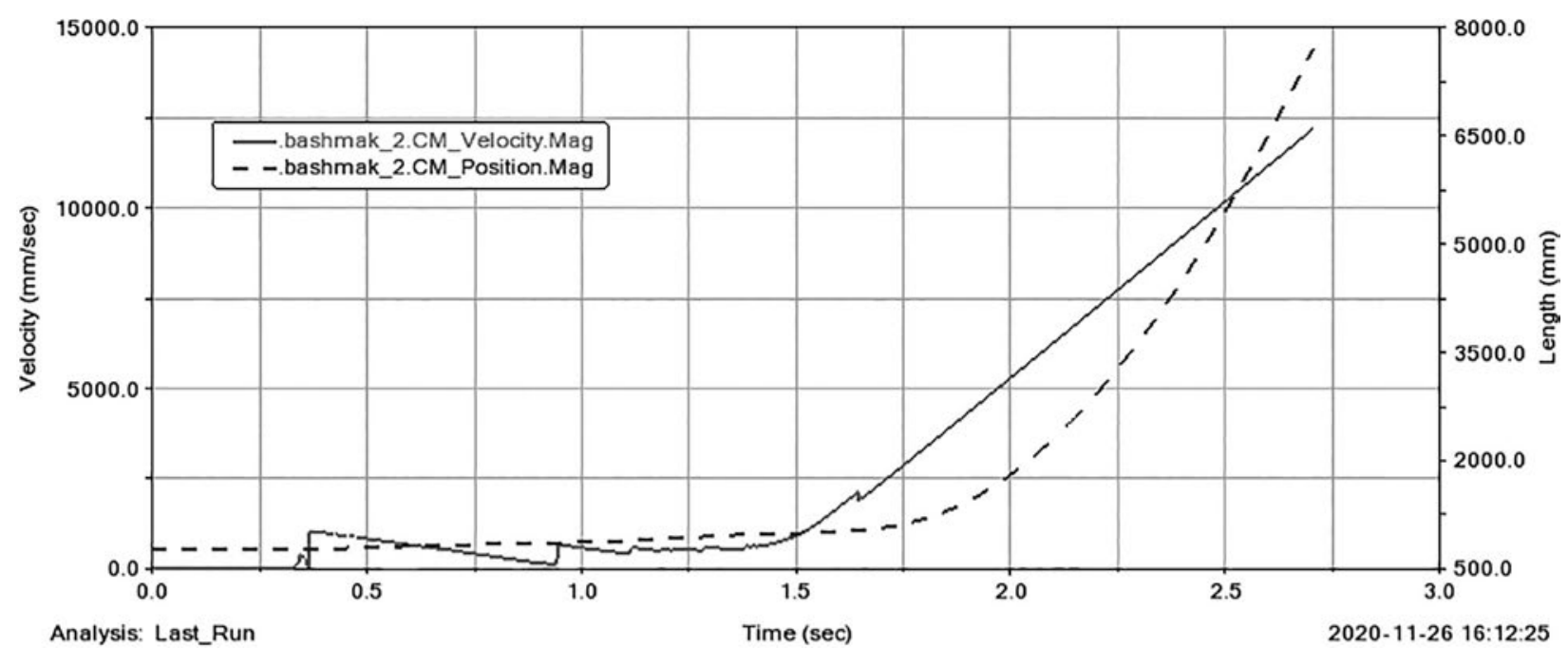

Рисунок 7 - Скорость (сплошная линия) и координата (пунктир) тормозного башмака на горизонтальном пути при наезде на него колесной пары вагона, движущегося по скользким рельсам с начальной скоростью 0,5 м/с Figure 7 - Speed (solid line) and the coordinate (dotted line) of the brake shoe on a horizontal track when a car wheelset moving on slippery rails with an initial speed of $0.5 \mathrm{~m} / \mathrm{s}$ hits it

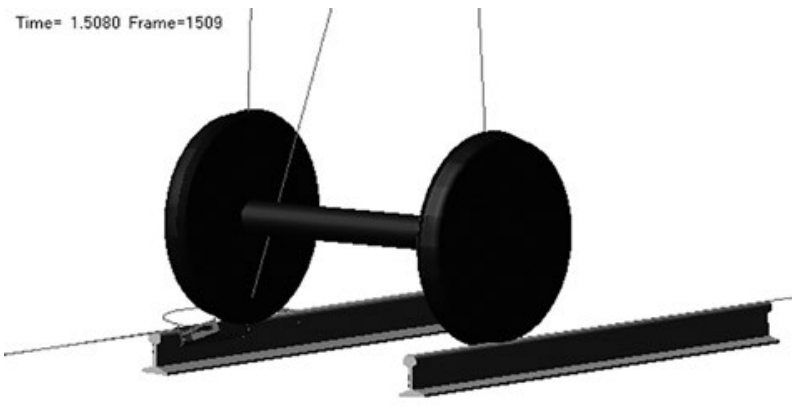

Рисунок 8 - Результаты расчета наезда колесной пары на одиночный башмак справа по ходу движения вагона для случая скользких рельсов

Figure 8 - Results of calculating the collision of a wheelset on a single shoe on the right in the course of the car movement for the case of slippery rails

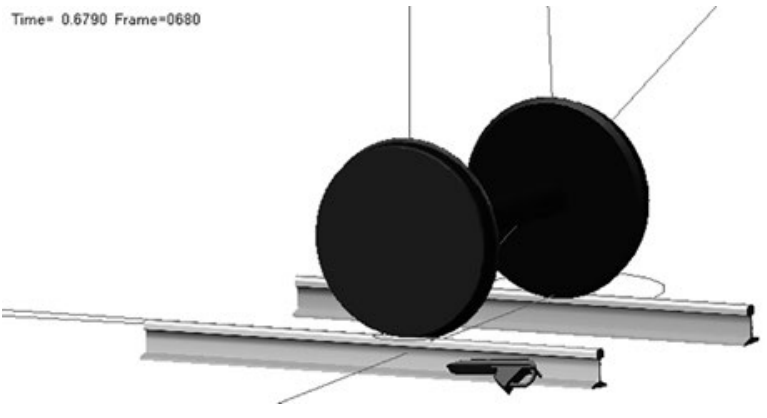

Рисунок 9 - Результаты расчета наезда колесной пары на одиночный башмак справа по ходу движения вагона

для случая одного сухого и одного скользкого рельсов

Figure 9-Results of calculating the collision of a wheelset on a single shoe on the right in the course of the car movement for the case of one dry and one slippery rails

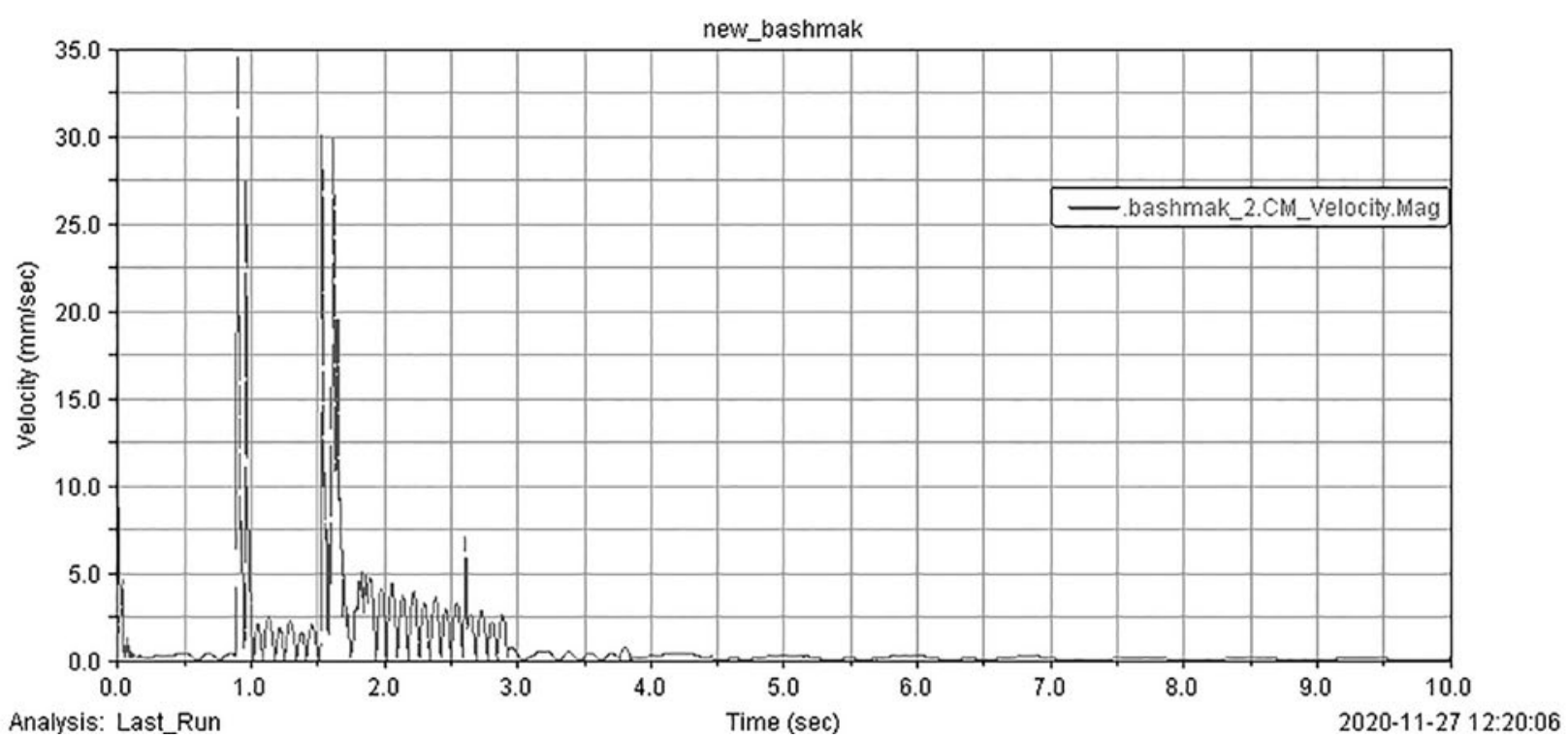

Рисунок 10 - Скорость центра масс башмака при удерживании колесной пары на скользких рельсах, находящихся на уклоне $2,5 \%$ Figure 10 - Speed of the shoe center of mass when keeping the wheelset on slippery rails that are on a slope of $2.5 \%$

Изменение уклона на 1,5 \%о практически не меняет ситуацию для случая скользких рельсов. Если же рельсы сухие (динамический коэффициент трения равен 0,4$)$, то один тормозной башмак позволяет 


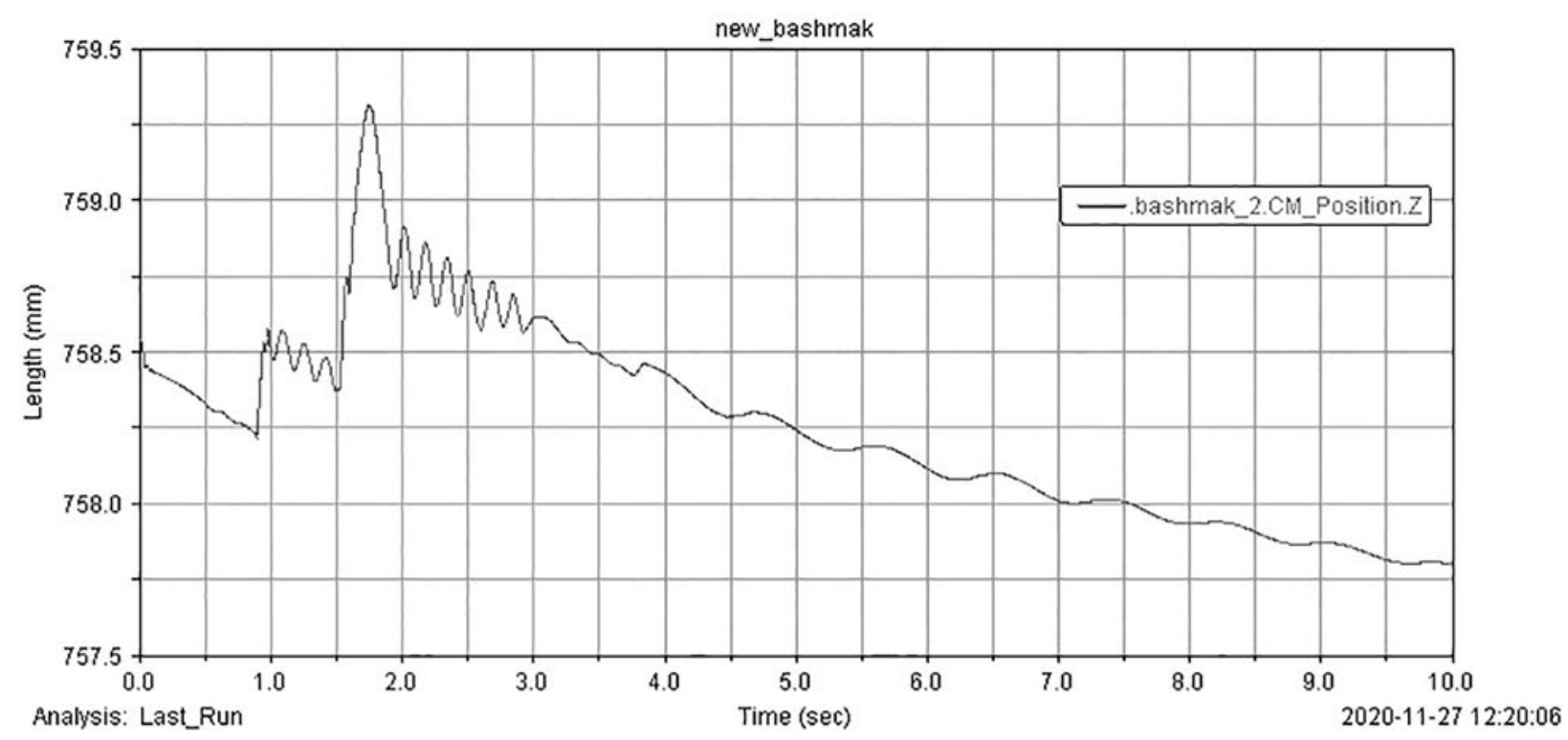

Рисунок 11 - Перемещение центра масс башмака при удерживании колесной пары на скользких рельсах в плоскости, перпендикулярной направлению движения колесной пары при уклоне 2,5\%о

Figure 11 - Movement of the shoe center of mass while keeping the wheelset on slippery rails in a plane perpendicular to the direction of wheelset movement at a slope of $2.5 \%$

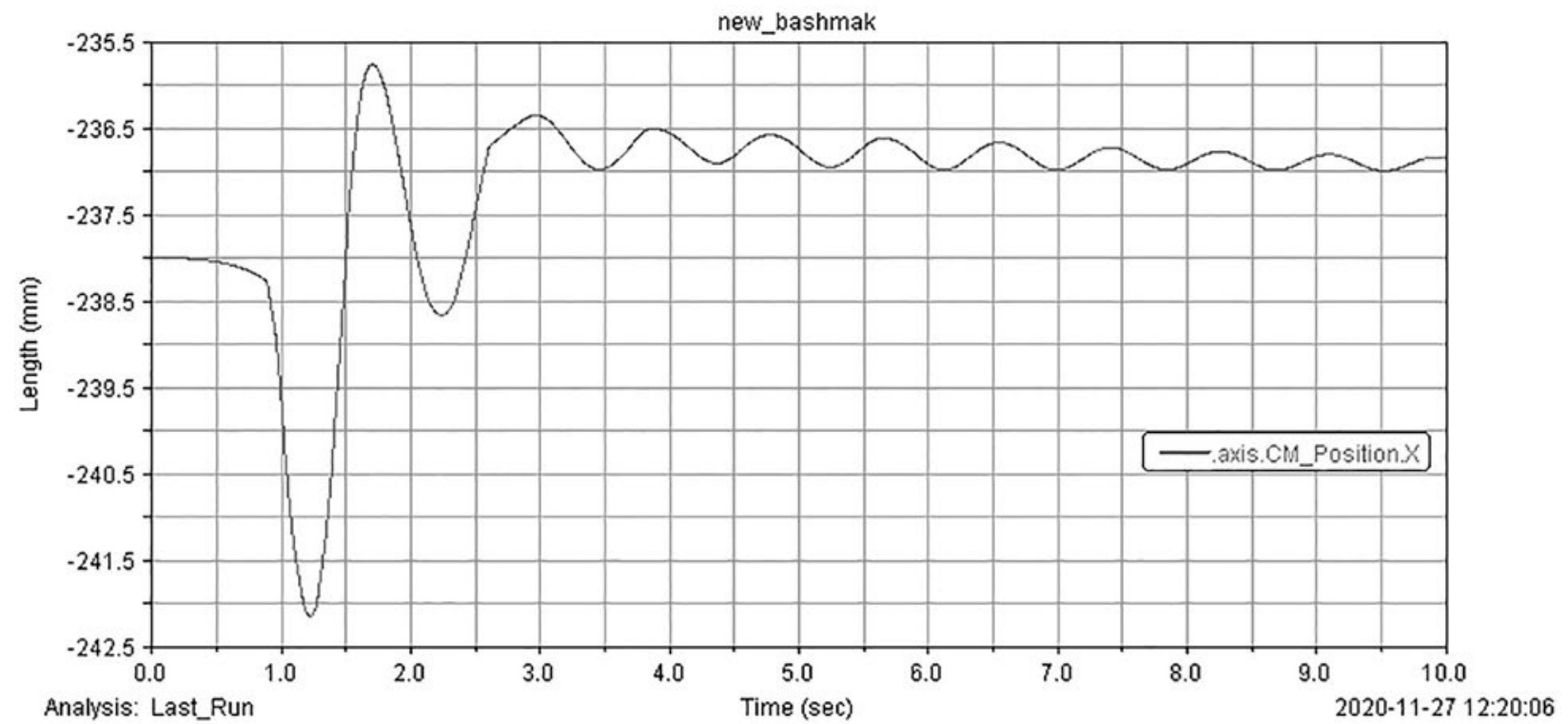

Рисунок 12 - Перемещение центра масс колеса при наезде на тормозной башмак из состояния покоя на скользких рельсах с уклоном $2,5 \%$

Figure 12 - Movement of the wheel center of mass when hitting the brake shoe from a state of rest on slippery rails with a slope of $2.5 \%$

удержать такую колесную пару, при этом имеет место его смещение на 1,8 мм (рисунок 13).

Таким образом, разработанная компьютерная модель позволила проанализировать эффекты, наблюдаемые при наезде колесной пары вагона на тормозной башмак. Установлено, что при установке башмаков на сухие незамасленные рельсы возможно обеспечить удержание как колесной пары, так и состава поезда от несанкционированного движения. В случае значительных уклонов при размещении вагонов на замасленных рельсах тормозные башмаки не всегда способны удержать железнодорожный состав от ухода. Наличие таких факторов, как боковая ветровая нагрузка, об- леденение рельсов, изношенность и деформация поверхности колеса и тормозного башмака, носит стохастический характер и может ухудшить условия удержания вагонов от скатывания за счет уменьшения площади контактной площадки в системах «колесо — рельс», «колесо — тормозной башмак» и «тормозной башмак - рельс», а также уменьшения динамического коэффициента трения между соприкасающимися поверхностями. Поэтому требуется применять дополнительные меры по закреплению состава на рельсах. Полученные результаты могут быть использованы при совершенствовании норм закрепления подвижного состава от ухода. 


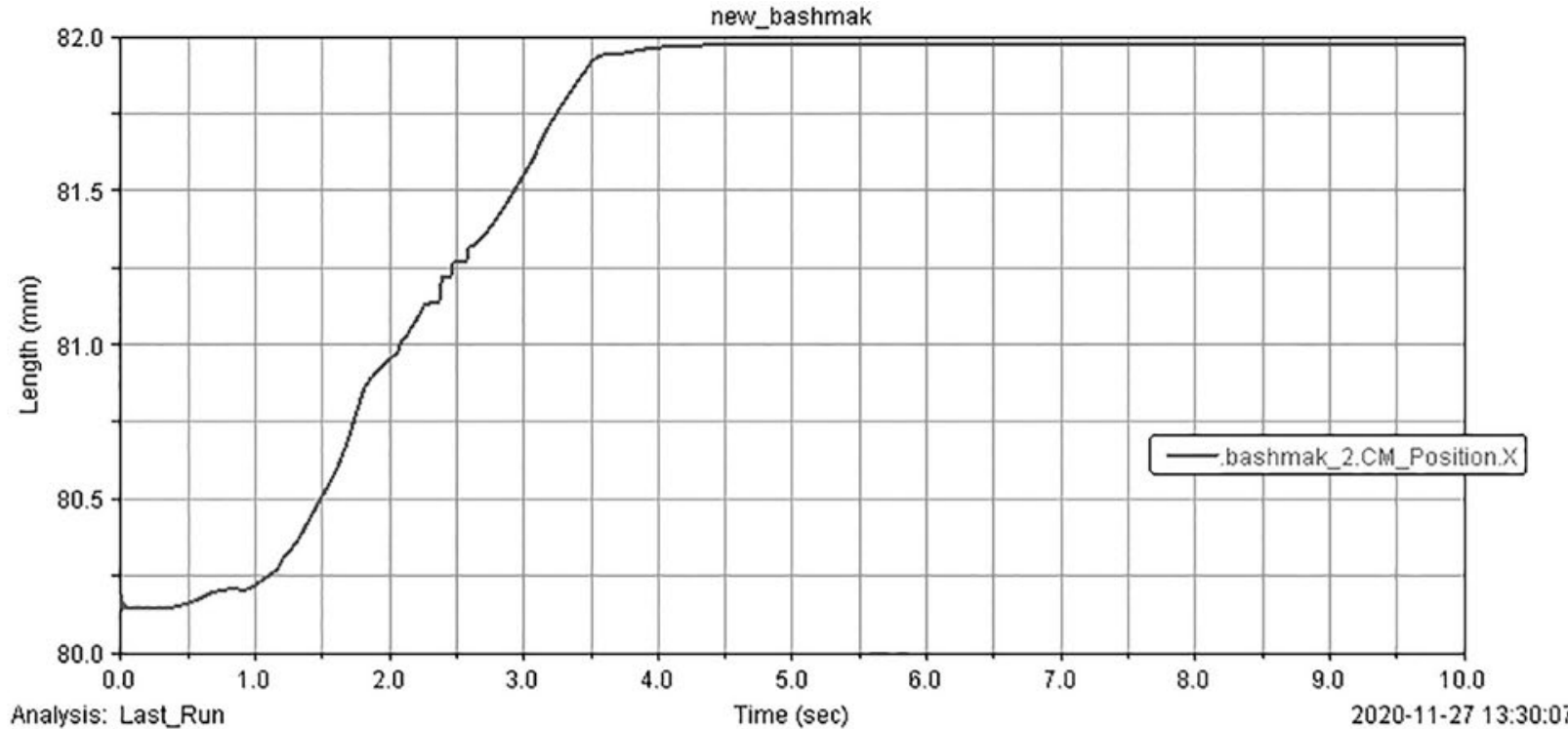

Рисунок 13 - Перемещение центра масс тормозного башмака при наезде на него колесной пары, движущейся из состояния покоя по сухим рельсам с уклоном 1,5\%

Figure 13 - Movement of the brake shoe center of mass when a wheelset hits it while moving from rest on dry rails with a slope of $1.5 \%$

\section{Список литературы}

1. Луговцов, М.Н. Проектирование железнодорожных станций и узлов: учеб. пособие для вузов / М.Н. Луговцов, В.Я. Негрей, В.А. Подкопаев. - Гомель: БелГУТ, 2004. - 159 с.

2. ALDON Company Inc. [Electronic resource]. - Mode of access: https://www.aldonco.com/PDFs/Catalog\%202019/Catalog2019-29-web.pdf. — Date of access: 20.06.2021.

3. Safetrack Baavhammar AB. [Electronic resource]. - Mode of access: https://www.safetrack.se/images/user/safetrackcatalogue.pdf. — Date of access: 20.06.2021.

4. Тормозной башмак с фрикционными элементами: пат RU 202936 / М.Ф. Капустьян, А.В. Обрывалин. - Опубл. 15.03.2021. - 7 c.

5. Тормозной башмак: пат. RU 2345922 C1 / И.П. Старшов, А.В. Николаев, В.Я. Берент, Е.Р. Шнейдерман, А.С. Бабий, Г.В. Горбунов. - Опубл. 10.02.2009. - 6 с.

6. Friction rail skate: pat US 8567571 / S.E. Neff, J.L. Lockridge, W.M. Scott. — Publ. date: 29.10.2013. — 21 p.

7. Anti-Runaway Prevention System with Wireless Sensors for Intelligent Track Skates at Railway Stations / C. Jiang [et al] // Sensors. - 2017. - Vol. 17, iss. 12. - 12 p. - DOI: https:// doi.org/10.3390/s17122955.

8. Fastening Device of the Railway Rolling Stock / A. Pinchuk [et al.] // ICTE in Transportation and Logistics. - 2019. Pp. 211-217.

9. Pinchuk, A. Improved rolling system of railway stock on brake shoe / A. Pinchuk [et al.] // Procedia Computer Science. 2019. - Vol. 149. - Pp. 258-263.
10. Козаченко, Д.М. Проблеми закріплення рухомого складу на коліях залізничних станцій / Д.М. Козаченко // Залізничний транспорт України. - 2013. - Вип. 3/4 (100/101). - С. 69-73.

11. Modeling and analysis of wag7 locomotive brake hanger / P.N.V. Balasubramanyam [et al.] // International Journal of Pure and Applied Mathematics. - 2017. — Vol. 116, no. 6. - Pp. 173-177.

12. Wu, Q. Train braking simulation with wheel-rail adhesion model/ Q. Wu, C. Cole, M. Spiryagin // Vehicle system dynamics. 2020. - Vol. 58, no. 8. - Pp. 1226-1241. — DOI: https://doi.or $\mathrm{g} / 10.1080 / 00423114.2019 .1645342$.

13. Чебаков, М.И. Расчет температурных полей при взаимодействии тормозной колодки и железнодорожного колеса на основе термоупругой модели / М.И. Чебаков, А.А. Ляпин, И.В. Колесников // Вестн. РГУПС. - 2013. - № 2(50). - С. 76-79.

14. Gopinath, G. Analysis of redesigned brake shoe / G. Gopinath, P. Murali // Materials Today: Proceedings. - 2020. - Vol. 22. Pp. 507-513. — DOI: https://doi.org/10.1016/j.matpr.2019.08.105.

15. Шимановский, А.О. Изменение напряженно-деформированного состояния элементов дискового тормоза при торможении / А.О. Шимановский, О.А. Суханова // Современные технологии. Системный анализ. Моделирование. - 2020. № 4(68). — C. 58-64. — DOI: https://doi.org/10.26731/18139108.2020.4(68).58-64

16. Study of the influence of the brake shoe temperature and wheel tread on braking effectiveness / P. Ivanov [et al.] // Journal of Physics: Conference Series. — 2020. — Vol. 1614, iss. 1. — DOI: https://doi.org/10.1088/1742-6596/1614/1/012086.

SHIMANOVSKY Alexandr O., D. Sc. in Eng., Prof.

Head of the Department "Technical Physics and Theoretical Mechanics"1

E-mail: tm.belsut@gmail.com

KUZNIATSOVA Marina G., Ph. D. in Eng., Assoc. Prof.

Associate Professor of the Department "Technical Physics and Theoretical Mechanics"1

E-mail: marina-kuzn@mail.ru

DZEMYANCHUK Volha U.

Student of the Faculty "Management of Transportation Processes"1

E-mail: olga.demyanchuk.98@mail.ru

${ }^{1}$ Belarusian State University of Transport, Gomel, Republic of Belarus 


\section{COMPUTER MODELING OF INTERACTION DYNAMICS OF THE RAILWAY CAR WHEELSET WITH BRAKING SHOES}

The paper considers the problem of keeping cars from rolling away on station railway tracks with a permissible slope of 0-2.5\%. The study presents the computer simulation results for the dynamic interaction of wheels with brake shoes installed on rails in the process of stopping a freight train car using standard brake shoes in the MSC.ADAMS engineering software package. In this case, various properties of the rail surface were taken into account, simulating favorable and unfavorable conditions for contact between the wheel, brake shoe and rail at braking due to both weather conditions and the peculiarities of station tracks location and operation. The interaction of the car wheels with the maximum axle load and the station brake shoes installed on the rails was studied at different initial velocities of the vehicle movement, as well as when it is at rest on tracks with the permissible slope under the conditions of ensuring the minimum friction between the wheel and the rail, as well as the interaction of rail and shoe was analyzed, which corresponds to the presence of the train on oily rails. It is demonstrated that it is not always possible for one brake shoe put on the oily rail to hold the train moving with the initial velocity more than $0.5 \mathrm{~m} / \mathrm{sec}$. Under other conditions of the wheel-brake shoe collision, the problem of keeping the train on the rails is also possible, due to such random factors as lateral wind load, rail icing, wear and deformation of the wheel surface and brake shoe, which reduce the dynamic friction coefficient between the contacting surfaces.

Keywords: brake shoe, rail surface, computer simulation, wheelset, MSC.ADAMS

DOI: https://doi.org/10.46864/1995-0470-2021-4-57-48-55

\section{References}

1. Lugovtsov M.N., Negrey V.Ya., Podkopaev V.A. Proektirovanie zheleznodorozhnykh stantsiy $i$ uzlov [Design of railway stations and junctions]. Gomel, Belorusskiy gosudarstvennyy universitet transporta Publ., 2004. 159 p. (in Russ.)

2. Rail Skids (Skates). Available at: https://www.aldonco. com/PDFs/Catalog\%202019/Catalog-2019-29-web.pdf (accessed 20 June 2021).

3. Product catalogue. Electrical bonding systems, equipment and materials for the railway industry. Available at: https:/www.safetrack. se/images/user/safetrack-catalogue.pdf (accessed 20 June 2021).

4. Kapustyan M.F., Obryvalin A.V. Tormoznoy bashmak $s$ friktsionnymi elementami [Brake shoe with friction elements]. Patent RU, no. 202936, 2021 (in Russ.).

5. Starshov I.P., Nikolaev A.V., Berent V.Ya., Shneyderman E.R., Babiy A.S., Gorbunov G.V. Tormoznoy bashmak [Brake shoe]. Patent RU, no. 2345922, 2009 (in Russ.).

6. Neff S.E., Lockridge J.L., Scott W.M. Friction rail skate. Patent US, no. 8567571, 2013. Available at: https://patents.justia.com/ patent/8567571 (accessed 30 June 2021).

7. Jiang C., Xu Y., Wen C., Chen D. Anti-Runaway prevention system with wireless sensors for intelligent track skates at railway stations. Sensors, 2017, vol. 17, iss. 12. DOI: https://doi.org/10.3390/ s17122955

8. Pinchuk A., Dadoenkov P., Baranovskis A., Nikolajevs A., Mukasheva A. Fastening device of the railway rolling stock. ICTE in transportation and logistics, 2019, pp. 211-217.

9. Pinchuk A., Dadoenkov P., Halutin D., Korago I. Improved rolling system of railway stock on brake shoe. Procedia computer science, 2019, no. 149, pp. 258-263.

10. Kozachenko D.M. Problemy zakreplenniya podvizhnogo sostava na putyakh zheleznodorozhnykh sostavov [Problems of fixing rolling stock on the tracks of railway stations]. Railway transport of Ukraine, 2013, iss. 3/4 (100/101), pp. 69-73.

11. Balasubramanyam P.N.V., Saida Rao B., Prem Kumar Reddy I., Narendra B.V., Venkata Sai M. Modeling and analysis of WAG7 locomotive brake hanger. International journal of pure and applied mathematics, 2017, vol. 116, no. 6, pp. 173-177.

12. Wu Q., Cole C., Spiryagin M. Train braking simulation with wheel-rail adhesion model. Vehicle system dynamics, 2020, vol. 58, no. 8, pp. 1226-1241. DOI: https://doi.org/10.1080/004 23114.2019.1645342.

13. Chebakov M.I., Lyapin A.A., Kolesnikov I.V. Raschet temperaturnykh poley pri vzaimodeystvii tormoznoy kolodki i zheleznodorozhnogo kolesa na osnove termouprugoy modeli [Calculation of the interaction of brake pad and train wheels based on thermoelastic model]. Vestnik Rostovskogo gosudarstvennogo universiteta putey soobshcheniya, 2013, no. 2(50), pp. 76-79 (in Russ.).

14. Gopinath G., Murali P. Analysis of redesigned brake shoe. Materials today: Proceedings, 2020, vol. 22, pp. 507-513. DOI: https://doi.org/10.1016/j.matpr.2019.08.105.

15. Shimanovsky A.O., Sukhanova V.A. Izmenenie napryazhenno-deformirovannogo sostoyaniya elementov diskovogo tormoza pri tormozhenii [Change in stress-strain state of disc brake elements during braking]. Modern technologies. System analysis. Modeling, 2020, no. 4(68), pp. 58-64. DOI: https:// doi.org/10.26731/1813-9108.2020.4(68).58-64 (in Russ.).

16. Ivanov P., Khudonogov A., Dulskiy E., Manuilov N., Khamnaeva A., Korsun A., Treskin S. Study of the influence of the brake shoe temperature and wheel tread on braking effectiveness. Journal of physics: Conference series, 2020, vol. 1614, iss. 1. DOI: https://doi.org/10.1088/1742-6596/1614/1/012086. 